\title{
Advances in photocatalysis in China
}

\author{
ZHENG Yun, PAN Zhiming, WANG Xinchen* \\ Research Institute of Photocatalysis, College of Chemistry and Chemical Engineering, Fuzhou University, Fuzhou 350002, Fujian, China
}

\section{A R T I C L E I N F O}

\section{Article history:}

Received 19 December 2012

Accepted 30 January 2013

Published 20 March 2013

\section{Keywords:}

Photocatalysis

Semiconductor

Solar energy

Water splitting

\section{A B S T R A C T}

We briefly describe the developments in photocatalysis research in China in the three time periods of 1975-1985, 1985-1995, and 1995-2012, focusing on advances in photocatalytic materials and their modifications, applications, and reaction mechanisms. This short review also indicates some vital problems and future development trends in photocatalysis for water splitting, $\mathrm{CO}_{2}$ reduction, environmental purification, and selective organic photosynthesis.

(C) 2013, Dalian Institute of Chemical Physics, Chinese Academy of Sciences. Published by Elsevier B.V. All rights reserved.

\section{Introduction}

1972 witnessed the landmark event of water photolysis on a $\mathrm{TiO}_{2}$ electrode by Fujishima and Honda in Japan [1], called the 'Fujishima-Honda effect'. Generally, a semiconductor photocatalytic process is induced by light illumination by a transition of electrons from the valance band (VB) of the photocatalyst to its conduction band (CB) giving holes in the valance band. The light-induced electrons and holes are transferred from the bulk to the surface of the catalyst to react with surrounding electron donors and electron acceptors, respectively. The photocatalytic process is an artificial photosynthesis process that mimics plant photosynthesis. In natural photosynthesis, sunlight, water, and carbon dioxide are converted into carbohydrates and oxygen. In the artificial version of photosynthesis, the strategy is to capture and store energy from sunlight in the chemical bonds of fuels such as hydrogen and hydrocarbons. Photocatalytic water splitting, which splits water into hydrogen and oxygen, is a main research field in artificial photosynthesis. Photo-induced carbon dioxide reduction is another important topic for replicating nat- ural carbon fixation (see Fig. 1). These important chemical conversions have attracted considerable worldwide attention and stimulated scientific activities to study the relevant chemical conversions by a photocatalyst and solar energy under the mild conditions of room temperature and room pressure.

\section{Development of photocatalysis in China}

In the past 40 years, China published about 11868 publications on photocatalysis (ISI web of Science), accounting for nearly $1 / 3$ of the total number (ca. 36617) of world publications (Table 1). In Fig. 2, it can also be seen that there was scarcely any research on photocatalysis in China before 1995, while from 1995-2012 photocatalysis research grew exponentially, which was due to the rapid economic growth of China and the accelerated homecoming trend of Chinese researchers from Japan, America and European countries.

In this short review, the development of photocatalysis in China is therefore divided into three periods: 1975-1985, 1985-1995, and 1995-2012. In the 1975-1985 period, intense

\footnotetext{
* Corresponding author. Tel/Fax: +86-591-83920097; E-mail: xcwang@fzu.edu.cn

This work was supported by the National Basic Research Program of China (973 Program, 2013CB632405) and the National Natural Science Foundation of China (21033003 and 21173043).

DOI: 10.1016/S1872-2067(12)60548-8 | http://www.sciencedirect.com/science/journal/18722067 | Chin. J. Catal.,Vol. 34, No. 3, March 2013
} 


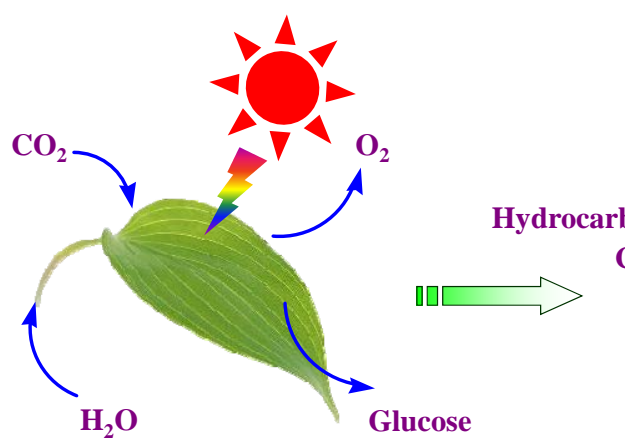

Natural Photosynthesis

Fig. 1. Natural photosynthesis and artificial photosynthesis.

researches were carried out on photocatalytic hydrogen evolution using metal complexes or semiconductor nanoparticles. In the 1985-1995 period, the study of the photocatalytic decomposition of pollutants and photocatalytic reduction of heavy metal ions became popular. The 1995-2012 period saw the diversified development of photocatalysis in all its aspects, including the search for new solar energy transducers (light harvesters or photocatalysts) and cofactors/cocatalysts, modification of the bulk and surface of photocatalysts, struc-

Table 1

Top five contributors to photocatalysis in 1975-2012 sorted by countrya.

\begin{tabular}{lcc}
\hline Country & Number of papers & Contribution $(\%)^{\mathrm{b}}$ \\
\hline China & 11868 & 32.4 \\
Japan & 5447 & 14.9 \\
USA & 4307 & 11.8 \\
South Korea & 1979 & 5.4 \\
India & 1839 & 5.0 \\
\hline
\end{tabular}

a Statistics from Web of knowledge, Thomson Reuters. The search strategy was as follows: Topic $=$ (photocataly ${ }^{*}$ ), Timespan $=$ 1975-01-01-2012-12-08, Databases = SCI-EXPANDED, CPCI-S, and Lemmatization $=$ On. Paper included journal article, proceeding papers, review, meeting abstract, etc.

${ }^{\mathrm{b}}$ Contribution $=$ paper number $/$ total paper number.

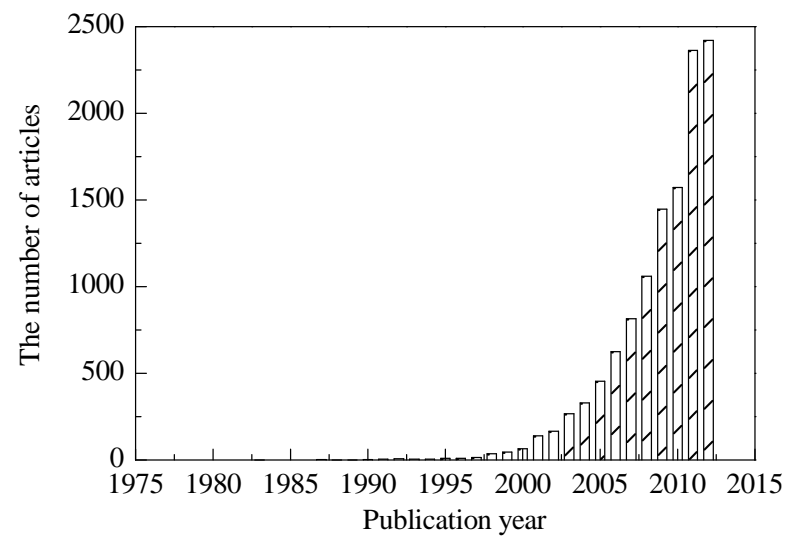

Fig. 2. Number of papers on photocatalysis in China by year. Statistics were collected from Web of knowledge, Thomson Reuters. The search strategy was as follows: Address $=($ China $)$, Topic $=\left(\right.$ photocataly $\left.{ }^{*}\right)$, Analysis: Countries/Territories $=($ PEOPLES R CHINA $)$, Timespan $=$ 1975-01-01-2012-12-08, Databases = SCI-EXPANDED and CPCI-S, Lemmatization $=$ On . ture-performance relationships, basic applications of photocatalytic functional materials, and photocatalytic mechanism studies. This was largely due to advances in nanotechnology and advanced characterization techniques such as TEM, EELS, ESR and XPS [2]. However, for the large scale production of solar hydrogen and chemical fuels as well as getting deep insights on the photocatalytic process, more development is still needed that would rely on innovative breakthroughs in various associated research fields, such as material science, surface/interface science, catalysis, biology, electrochemistry and so on, and then integrating their knowledge gained into photocatalysis research.

\section{Development in the mid-1970s (1975-1985)}

Artificial photosynthesis and solar energy conversion have long been listed as one of the fourteen major projects in China in the 'National Compendium on Basic Scientific Development (1975-1985)'. Photocatalytic hydrogen evolution from water was seen as an ideal and the simplest pathway to utilize clean, abundant and economic solar energy, and the field developed rapidly in China. It received the attention of many scientific research institutions and universities, including Dalian Institute of Chemical Physics of Chinese Academy of Sciences, Lanzhou Institute of Chemical Physics of Chinese Academy of Sciences, Jilin University, Shandong University, Wuhan University and so on. Photocatalytic water splitting using solar energy and powder photocatalysts received extensive attention. In general, the photocatalytic water splitting systems can be classified into two types, namely, homogenous systems involving metal complexes as photosensitizers and heterogeneous systems composed of semiconductor nanoparticles.

Metal complexes were used as photosensitizers for photocatalytic water splitting. A major system for photocatalytic water splitting comprised a photosensitizer ( $\mathrm{Ru}$ or Rh complex), electron mediator $\left(\mathrm{MV}^{2+}\right.$ or $\mathrm{Ru}(\mathrm{bpy})_{3}{ }^{2+}$ ), electron donor (TEOA or EDTA), surfactant, and other additives [3]. The use of metal porphyrins with active groups as a photosensitizer increased the efficiency of water splitting by the prevention of the reverse reaction and better stability and repeatability [4,5]. A similar result was seen in the system with $\mathrm{Ru}(\mathrm{bpy}) 3^{2+}$ developed by Grätzel and co-researchers in Switzerland [6]. In addition, 
semiconductor nanoparticles were also used for photocatalytic water splitting and organic synthesis because of their easy scale-up by the thin film design of photocatalytic layers. Hydrogen and ethylene glycol production by light-induced dehydrogenative $\mathrm{C}-\mathrm{C}$ coupling were also reported with powder photocatalytic systems containing $\mathrm{ZnS}$, methanol, and water [7]. It was important that the high evolution rate of hydrogen and the high selectivity (95\%) of ethylene glycol approached the advanced international standards [7].

\section{Progress in the 1980s (1985-1995)}

In the mid-1980s, research on photocatalytic water splitting reached its low point, while the study of the photocatalytic decomposition of pollutants and photocatalytic reduction of heavy metal ions reached its peak. Environmental photocatalysis was more popular than energy photocatalysis because of the growing concern with environmental problems associated with rapid economic growth.

The cleavage of sulfide was achieved in a semiconductor nanoparticles suspension. CdS was widely used as a representative photocatalyst for the degradation of organic pollutants. Photodeposition of $\mathrm{RuO}_{2}$ or $\mathrm{Rh}_{2} \mathrm{O}_{3}$ on the surface of $\mathrm{CdS}$ was an effective method to avoid the light corrosion behavior of CdS by enabling the fast separation and transfer of light-induced electrons and holes, which thus prevented charge built-up on the surface of the catalyst [8]. A photocatalytic system consisting of $\mathrm{Rh}_{2} \mathrm{O}_{3} / \mathrm{CdS}$ displayed activity in the cleavage of $\mathrm{H}_{2} \mathrm{~S}$ or sulfide into hydrogen and sulfur under visible light irradiation. The reflectance spectra of $\mathrm{CdS}$ and $\mathrm{Rh}_{2} \mathrm{O}_{3} / \mathrm{CdS}$ confirmed that $\mathrm{Rh}_{2} \mathrm{O}_{3}$ deposited on the $\mathrm{CdS}$ particles promoted light absorption in the visible region [8]. The photocatalytic technique was explored to solve the problem of aqueous $\mathrm{H}_{2} \mathrm{~S}$ pollutants generated by tanneries, paper mills, oil refineries, chemical plants, and coal plants.

Toxic heavy metal ions can be reduced and detoxified by photocatalysis technology. The reduction of $\mathrm{Hg}$ (II) on

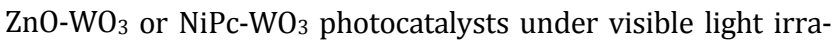
diation was investigated by Zhuang and co-workers [9]. Hg (II) $(100 \mu \mathrm{g} / \mathrm{ml})$ can be almost $100 \%$ photoreduced by $\mathrm{ZnO}-\mathrm{WO}_{3}$,

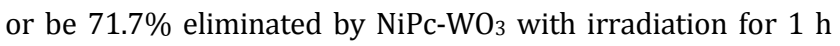
[9]. In addition, CdS with different crystal structures were demonstrated to give a remarkable effect on the photocatalytic reduction of $\mathrm{Cr}$ (VI) under visible light illumination [10]. The photoreduction rate of the $\mathrm{Cr}$ (VI) pollutant was greatly improved with either an artificial light source or with sunlight [10]. The photocatalytic reduction of heavy metal ions provided a new pathway for environmental protection under mild conditions.

\section{Development in the period of 1995-2012}

The first generation photocatalysts were mainly $\mathrm{TiO}_{2}$-based semiconductors. Many synthesis methods for $\mathrm{TiO}_{2}$ have been developed, such as the sol-gel method, micelle and inverse micelle methods, hydrothermal method, solvothermal method, direct oxidation method and so on [11]. As breakthroughs were made in the preparations and applications of $\mathrm{TiO}_{2}$ materials, many reviews were published [12,13].

As a photocatalyst, $\mathrm{TiO}_{2}$ has many advantages, including water insolubility, hydrophilicity, non-toxicity, cheapness and easy availability, biological compatibility, photostability and having the proper band potentials, which make it a useful material for photocatalytic applications, particularly for the complete oxidation of organic pollutants to $\mathrm{CO}_{2}$ and water. As the most well-known photocatalyst, $\mathrm{TiO}_{2}$ materials play a vital role in addressing many serious environmental challenges, and they give much hope for overcoming the energy crisis by the effective use of solar photovoltaics, like the dye-sensitized solar cell. $\mathrm{TiO}_{2}$ is also a basic material for the construction of photocatalytic functional coatings and thin films on various materials to create 'smart' surfaces with self-cleaning, anti-bacterial and anti-fogging functions. Nowadays, many of these photocatalytic functional coatings have already been commercialized.

However, the defects of $\mathrm{TiO}_{2}$ should not be ignored. First, $\mathrm{TiO}_{2}$ has a large band gap energy $(3.0 \mathrm{eV}$ for the rutile phase and $3.2 \mathrm{eV}$ for the anatase phase) leading to a low utilization of the solar spectrum [14]. Second, the quantum yield is generally low due to the indirect excitation characteristics of the $\mathrm{TiO}_{2}$ semiconductor. Third, catalytic deactivation typically occurs when pure $\mathrm{TiO}_{2}$ is applied to the photocatalytic treatment of aromatic compounds, such as benzene and toluene. Therefore, it is necessary to design and modify the physicochemical properties of titania to narrow its band gap, enhance its activity and stability, and also to control its catalytic selectivity. Various strategies have been tried for this purpose, including morphology control, facet control, nanostructuring, noble metal deposition, doping, secondary semiconductor coupling, sensitization, surface superacidification and so on.

\subsection{Modification of $\mathrm{TiO}_{2}$ photocatalysts}

In recent years, the controllable synthesis of materials with a desired morphology has drawn attention as it was found that material properties are governed by their morphology. One-dimensional (1D) nanostructures, such as rods, wires, belts and tubes [15], have been intensively investigated due to their extraordinary electronic, optical and chemical properties that allow applications in various fields. Rutile nanorod superstructures were reported to give higher photocatalytic activities than Degussa P25, which was attributed to their narrow band gap, large surface area, small crystal size, and high crystallinity [16]. Noble metal@ $\mathrm{TiO}_{2}$ core-shell heterostructures are novel photocatalysts with the combined advantages of the proper chemical composition, tunable chemical and colloidal stability within the shell, three dimensional interface, and promoted charge transfer kinetics [17]. The noble metal cores enhanced photocatalytic activity because of trapped electrons and the effective separation of electron and hole, as well as promoted visible light absorption. However, the incorporation of noble metal core lowers the UV light absorption capability, thus leading to a lower activity than bare $\mathrm{TiO}_{2}$ (see Fig. 3) [18].

The design of a single crystal with exposed highly reactive facets is a newly developed strategy to optimize the photocata- 


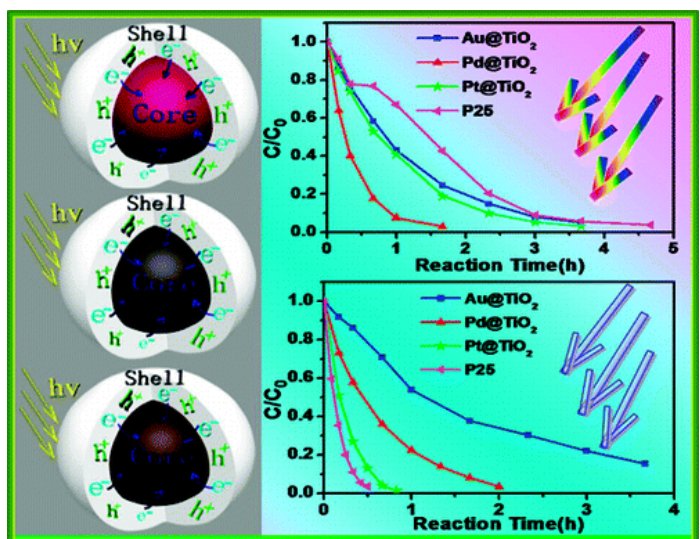

Fig. 3. Tunable photoactivity by encapsulating different noble metal $(\mathrm{Au}, \mathrm{Pd}, \mathrm{Pt})$ core into the $\mathrm{TiO}_{2}$ shell. Reproduced with permission from Ref. [18]; copyright 2011, American Chemical Society.

lytic performance of $\mathrm{TiO}_{2}$. This method has been successfully extended to the crystal facet engineering of other semiconductors and even metal nanocrystals for various advanced applications, including catalysis, photocatalysis, and electrochemistry. The $\{001\}$ facets of anatase $\mathrm{TiO}_{2}$ are considered to be more reactive than $\{101\}$ facets. An anatase $\mathrm{TiO}_{2}$ single crystal with $47 \%$ highly reactive $\{001\}$ facets was synthesized with hydrofluoric acid (HF) as a capping agent under hydrothermal conditions [19]. Hollow $\mathrm{TiO}_{2}$ microspheres with $20 \%$ exposed $\{001\}$ facets have been reported to exhibit tunable selectivity in the photocatalytic degradation of azo dyes [20]. It was also shown that anatase $\{101\}$ facets exhibited a higher photoactivity than the $\{001\}$ facets, and the $\{010\}$ facets exhibited the highest photocatalytic activity in generating hydroxyl radicals and having hydrogen evolved (see Fig. 4) [21].

Fabricating $\mathrm{TiO}_{2}$ in the form of nanosheets can provide more active sites on the surface and generate unique charge-bearing effects. Anatase $\mathrm{TiO}_{2}$ nanosheets exhibited excellent activity in the photocatalytic degradation of organic contaminants because of the exposure (up to 89\%) of highly reactive $\{001\}$ facets that were stabilized by fluorine ions on the facets [22]. When used with carbon supports, anatase $\mathrm{TiO}_{2}$ sheets with exposed high energy $\{001\}$ facets supported on

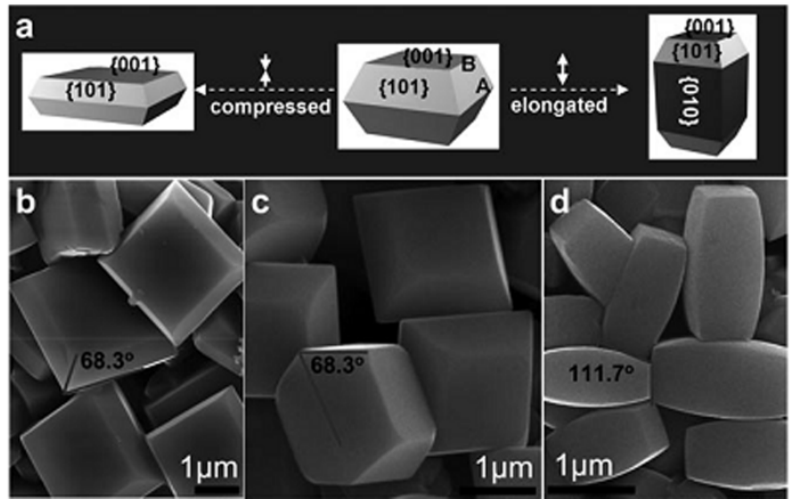

Fig. 4. Morphology and atomic structure of anatase $\mathrm{TiO}_{2}$ crystals. (a) Schematic of anatase $\mathrm{TiO}_{2}$ with different percentages of $\{101\},\{001\}$, and $\{010\}$ facets. b-d) SEM images of anatase crystals with the dominant facet of 001/101/010 (b-d). Reproduced with permission from Ref. [21]; copyright 2011, Wiley-VCH. carbon fibers exhibited an improvement in the photocatalytic degradation of methyl orange by a factor of 3.38 in comparison with $\mathrm{TiO}_{2}$ nanosheets grown on a planar substrate [23]. The application of the different redox reactivities of the different crystal facets also has great promise for controlling the surface redox chemistry of a photocatalyst, e.g. by the selective deposition of reductive and oxidative co-factors on the different facets of a crystal, thus locally separating oxidation and reduction reactions in nanospaces. This is especially important for overall water splitting to generate $\mathrm{H}_{2}$ and $\mathrm{O}_{2}$, as oxidation and reduction are locally incompatible and they must be strictly separated in nanodomains.

The creation of a nanoporous structure in $\mathrm{TiO}_{2}$ photocatalysts has attracted much attention, being considered as an effective pathway to modify the catalyst texture and its optical absorption. Advances in surfactant-templated sol-gel chemistry for the fabrication of mesoporous materials have boosted scientific activities in the design and synthesis of various nanoporous $\mathrm{TiO}_{2}$ both in the form of powders and thin films. Yu and coworkers reported that mesoporous $\mathrm{TiO}_{2}$ with a combination of anatase and brookite phases exhibited a better photocatalytic activity than P25 (mixture of anatase and rutile) in the degradation of $n$-pentane [24]. Hierarchical macro/mesoporous titania can be fabricated by using mixed surfactants or by a simple hydrolysis of tetrabutyltitanate without additives followed by heating. The material was demonstrated to be an interesting photocatalyst for environmental purification $[25,26]$. Excellent photocatalytic activity is present in mesoporous $\mathrm{TiO}_{2}$ materials with a specific morphology, such as sponge-like macro/mesoporous titania [27], mesoporous titania hollow microspheres [28], and mesoporous titania nanorod/titanate nanotube composites [29], especially when the reaction kinetics are diffusion limited. Advances in nanostructured and nanoporous photocatalysts provide new opportunities for host-guest chemistry by the inclusion or stabilization of functional guest species that are optically, magnetically, and electronically active in the photocatalytic framework.

Noble metal deposition is a way to improve the properties of a semiconductor photocatalyst host, by increasing catalytic rates and charge-separation rates. Material properties, such as the type, size and concentration of the noble metal particles, together with the preparation method, were demonstrated to have a strong effect on the promoted catalytic function of the metals. Well dispersed Ag particles in the proper loading amount promoted the photocatalytic oxidation of aniline [30]. Very recently, plasmonic photocatalysts have played an important role in visible light-sensitive photocatalysts by hot electron injection from the plasmonic metal nanoparticles to the semiconductor. In metal-semiconductor composite photocatalysts, the noble metal nanoparticles can utilize visible light due to their surface plasmon resonance, and then the electron is transferred to the semiconductor, locally separating photogenerated electrons and holes for redox chemistry (see Fig. 5) [31]. A plasmonic photocatalyst of $\mathrm{Ag} / \mathrm{AgCl} / \mathrm{TiO}_{2}$ nanotubes gave a superior photocatalytic activity in the degradation of methyl orange under visible light irradiation [32]. It is noted that the metal-induced gap in $\mathrm{AgCl}$ was already reported 30 


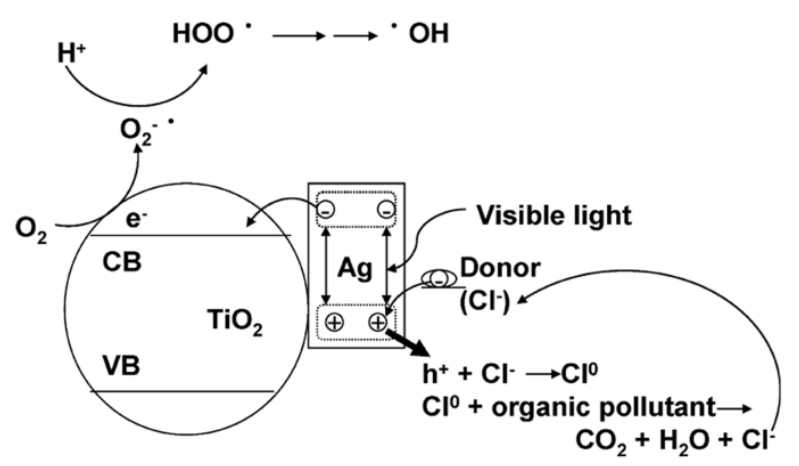

Fig. 5. Schematic diagram for the charge separation in a visible light irradiated $\mathrm{Ag} / \mathrm{AgCl} / \mathrm{TiO}_{2}$ system. Reproduced with permission from Ref. [32]; copyright 2009, American Chemical Society.

years ago to visibilize the system for water oxidation to liberate oxygen, and it is now shown that this plasmon-induced water splitting chemistry can be extended to other photocatalytic applications such as environmental purification, selective organosynthesis and more.

Doping is an alternative way to modify $\mathrm{TiO}_{2}$ by introducing impurity levels in the $\mathrm{TiO}_{2}$ mid-gap structure to tune the physical and chemical properties of the photocatalysts. Transition metal ion $\left(\mathrm{Fe}^{3+}, \mathrm{Cr}^{6+}, \mathrm{V}^{4+}\right)$, rare earth metal ion $\left(\mathrm{Ce}^{4+}, \mathrm{Gd}^{3+}, \mathrm{Y}^{3+}\right.$, $\left.\mathrm{La}^{3+}, \mathrm{Nd}^{3+}, \mathrm{Tb}^{3+}\right)$, noble metal ion $\left(\mathrm{Au}^{3+}, \mathrm{Ag}^{+}, \mathrm{Ru}^{3+}\right)$ and others have been widely applied as dopants for $\mathrm{TiO}_{2}$, while nonmetallic ion dopants are C, N, B, F, P, S, Br and Cl. The photocatalytic activity of $\mathrm{TiO}_{2}$ under UV light irradiation and visible light irradiation was improved by doping $\mathrm{Fe}^{3+}$ at optimal concentrations of $0.1 \%$ and $0.2 \%$, respectively [33]. By a proper $\mathrm{Fe}^{3+}$ doping, photo-induced electrons and holes were efficiently separated under UV light irradiation [33]. However, it was also proposed that $\mathrm{Fe}^{3+}$ dopants acted as recombination centers for electrons and holes, which is detrimental to photocatalysis. $\mathrm{Yu}$ and coworkers developed F-doped $\mathrm{TiO}_{2}$ with both anatase and brookite phases, and found that the photocatalytic activity exceeded that of Degussa P25, due to the improved crystallinity, increased amount of the anatase phase, and improved optical absorption in the UV-visible range [34]. $\mathrm{TiO}_{2}$ co-doped with proper concentrations of $\mathrm{Eu}^{3+}$ and $\mathrm{Fe}^{3+}$ showed enhanced photocatalytic activity as compared with undoped $\mathrm{TiO}_{2}$ [35]. In this co-doped system, $\mathrm{Fe}^{3+}$ acted as a hole trap and $\mathrm{Eu}^{3+}$ as an electron trap, so that the interfacial charge transfer rate was much increased [35].

Coupled/composite $\mathrm{TiO}_{2}$ systems have been intensively investigated too, and in some cases they displayed a superior photocatalytic performance to a single component material. For example, the photocatalytic performance of $\mathrm{WO}_{x}-\mathrm{TiO}_{2}$ for the degradation of methylene blue in aqueous solution under visible light irradiation was dramatically improved over unmodified $\mathrm{TiO}_{2}$. [36]. Significantly, the surface phase junction and heterojunction formed in composite semiconductors contributed to the enhanced photocatalytic activity by promoting the collection and separation of charges in the interfaces [37]. La$\mathrm{VO}_{4} / \mathrm{TiO}_{2}$ nanocomposite catalysts were reported to exhibit a high photocatalytic activity in the decomposition of benzene due to the coordinated band potentials and the heterojunction structure that was formed by the close contact of $\mathrm{LaVO}_{4}$ and $\mathrm{TiO}_{2}$ nanoparticles [38]. Besides, carbon not only works in collaboration with $\mathrm{TiO}_{2}$ due to its distinctive electron and hole transfer properties, but it also acts as a sensitizer for $\mathrm{TiO}_{2}$ for visible light photocatalysis. The photocatalytic performance of $\mathrm{C}_{60}$-hybridized $\mathrm{TiO}_{2}$ under UV irradiation was enhanced due to the efficient transport of photo-induced electrons at the interface [39]. $\mathrm{TiO}_{2}$-graphene nanocomposites were actively investigated and have been reported to exhibit much higher photocatalytic activity and stability than bare $\mathrm{TiO}_{2}$ in the gas phase degradation of benzene [40]. There are concerns that the excessive usage of black carbon-based materials to couple/mix with photocatalysts can cause a light shielding effect, and thus an optimization of these two factors should be considered in designing carbon-promoted semiconductor photocatalysts.

Sensitization is an effective surface modification method for changing a wide bandgap photocatalyst to a visible light-responsive material for solar applications. The sensitizers are typically noble metal complexes $(\mathrm{Ru}, \mathrm{Pd}, \mathrm{Pt}, \mathrm{Rh}$, and $\mathrm{Au}$ chlorides) and various organic dyes (chlorophyllin, ruthenium bipyridine, eosin, phthalocyanine, porphyrine, rose red, and so on), which promote the light harvesting capability of the photocatalyst. Effective sensitization also requires surface and texture engineering of the host photocatalyst to enhance the affinity of the host matrix towards the stabilization of the dyes in the nanoscale pores. Dye-sensitized $\mathrm{TiO}_{2}$ has drawn much attention in photocatalytic hydrogen evolution and solar cells. Visible light-induced hydrogen evolution has been realized with a dye-sensitized $\mathrm{M} / \mathrm{TiO}_{2}(\mathrm{M}=\mathrm{Pt}, \mathrm{Ru}$, and $\mathrm{Rh})$ [41] or a dye-sensitized $\mathrm{CuO} / \mathrm{TiO}_{2}$ composite catalyst [42].

Increasing the surface acidity of a catalyst is an important way to improve photocatalytic efficiency. The surface acidity of a solid state metal oxide typically refers to the surface polar hydroxyl groups (Brönsted acidic sites) and metal cations (Lewis acidic sites), which find many applications in acid catalysis for bulk and fine chemicals production. Fu and coworkers [43] introduced surface acidity as an effective tool to promote heterogeneous photocatalysis. They developed a solid superacid photocatalyst $\mathrm{SO}_{4} 2^{-} / \mathrm{TiO}_{2}$ that has strong surface acidity, enhanced texture, good stability, and excellent photocatalytic performance in the degradation of organic pollutants in the gas phase. The sulfation treatment of amorphous $\mathrm{TiO}_{2}$ followed by thermal sintering at $450-500{ }^{\circ} \mathrm{C}$ typically enlarges the band gap and blue shifts the band edge to generate a larger redox potential due to the quantum size effect, which thus increased the photocatalytic activity. The creation of surface Brönsted and Lewis acidic sites enhanced the surface reactivity of the materials, and also has an additional value in photocatalysis by promoting charge separation on the surface. Moreover, the photocatalytic property of $\mathrm{SO}_{4}{ }^{2-} / \mathrm{TiO}_{2}$ was affected by the impregnation concentration of the $\mathrm{H}_{2} \mathrm{SO}_{4}$ solution [44]. In addition to $\mathrm{SO}_{4}{ }^{2-} / \mathrm{TiO}_{2}$, phosphated mesoporous titanium dioxide showed activity in the photo-oxidation of $n$-pentane due to the extended band gap energy, large surface area, and the existence of $\mathrm{Ti}$ ions in a tetrahedral coordination [45]. As a step towards industrialization, a pilot production line was built for applying the $\mathrm{TiO}_{2}$ based solid superacid photocatalyst as an air cleaner. 


\subsection{New generation photocatalyst}

In addition to $\mathrm{TiO}_{2}$-based photocatalysts, other materials were also used as light harvesters to create the photocatalysis effect in combination with co-catalysts. Diverse UV-active photocatalysts have been explored, including simple binary metal oxides and complex metal oxides with $\mathrm{d}^{0}$ and $\mathrm{d}^{10}$ electronic configurations, such as $\mathrm{Ga}_{2} \mathrm{O}_{3}$ [46], $\mathrm{BiOCl}$ [47], $\mathrm{Zn}_{2} \mathrm{GeO}_{4}$ [48], $\mathrm{SrNb}_{2} \mathrm{O}_{6}$ and $\mathrm{Sr}_{0.4} \mathrm{H}_{1.2} \mathrm{Nb}_{2} \mathrm{O}_{6} \cdot \mathrm{H}_{2} \mathrm{O}$ [49]. In order to harness solar energy more effectively and efficiently, the development of visible light-active photocatalysts is an urgent issue and a key research topic in photocatalysis today. Many novel visible light-responsive photocatalysts have been developed, such as $\mathrm{CdS}$ [50], $\mathrm{WO}_{3}$ [51], $\mathrm{Fe}_{2} \mathrm{O}_{3}$ [52], $\mathrm{Bi}_{2} \mathrm{WO}_{6}$ [53], $\mathrm{CaBi}_{2} \mathrm{O}_{4}$ [54]. Polyoxometalates (POMs, such as $\left.\mathrm{Mg}_{12} \mathrm{Al}_{6}(\mathrm{OH})_{36}\left(\mathrm{~W}_{7} \mathrm{O}_{24}\right) \cdot 4 \mathrm{H}_{2} \mathrm{O}\right)$ are a new type of photocatalysts attractive for their use in the photo-oxidation of organic substrates and their structural stability in a photo-induced multielectron transfer process [55].

In addition to inorganic photocatalysts, zeolites, metal-organic frameworks (MOFs), graphene and polymers also play important roles in the development of new photocatalytic materials that are responsive to visible light. Zeolites with special textures, structural and electronic properties have been applied to liquid and gas phase photocatalysis by taking advantage of impurities in the framework, such as iron ions [56]. Metal ions in ZSM-5 were reported by Chen's group to promote visible light-induced $\mathrm{C}-\mathrm{C}$ coupling of methane, while producing $\mathrm{H}_{2}$ as the only byproduct [57]. A new alternative photoactive system is microporous metal-organic frameworks (MOFs) composed of transition metal containing clusters and organic linkers [58]. Liu and coworkers introduced $\alpha$-sulfur crystals of cyclooctasulfur $\left(\mathrm{S}_{8}\right)$ as a cheap and easily available light harvester that was a visible light-active elemental photocatalyst in a photoelectrochemical process [59].

In carbon-containing systems, composite materials based on carbon nanotubes and photoactive oxides were applied to the photocatalytic reduction of $\mathrm{CO}_{2}$ with $\mathrm{H}_{2} \mathrm{O}$ [60]. Graphene (or graphene oxide)-based composite materials are significant in the future of photocatalytic hydrogen production and dye degradation (see Fig. 6) [61,62]. Polymeric $\mathrm{C}_{3} \mathrm{~N}_{4}$ was recently demonstrated as a new generation metal-free photocatalyst with a suitable band structure for water splitting, pollutant elimination and organic photosynthesis under visible light illumination [63-65] (see Fig. 7). The search for new, efficient, visible light-responsive materials is still the current frontier in photocatalysis, which requires efficient, stable, inexpensive, and composed of earth-abundant elements. The investigation of new photocatalysts can expand the scope of material science, bring about breakthroughs in photocatalysis, and provide an alternative way to tackle the challenge of artificial photosynthesis for addressing global energy and environmental issues.

\subsection{Materials for photocatalytic applications}

Photocatalytic technology can contribute greatly in environment protection and energy generation. Photocatalytic applications include the degradation of pollutants, water splitting, $\mathrm{CO}_{2}$ fixation/reduction, and organic synthesis. The development in the materials for these is classified by their application in this section.

\subsubsection{Materials for photocatalytic degradation of pollutants}

Toxic organic pollutants, especially persistent pollutants generated in domestic and industrial activities, are the urgent concerns of people, which calls for the development of environmentally-friendly advanced oxidation technology to treat the pollutants under mild conditions. Heterogeneous photocatalysis technology can easily induce the production of hydroxyl radicals for the purification and refreshment of water and air. Many materials have been applied to the photodegradation of organic contaminants in both gas and liquid phases with light irradiation. $\mathrm{TiO}_{2}$ and doped $\mathrm{TiO}_{2}$ were used for the photocatalytic decomposition of phenolic contaminants and various dyes [66-71]. Zhu et al. [72] found that $\mathrm{Bi}_{2} \mathrm{WO}_{6}$ nanostructures exhibited high activity in the degradation of organic compounds under visible light irradiation. Conjugated materials (such as
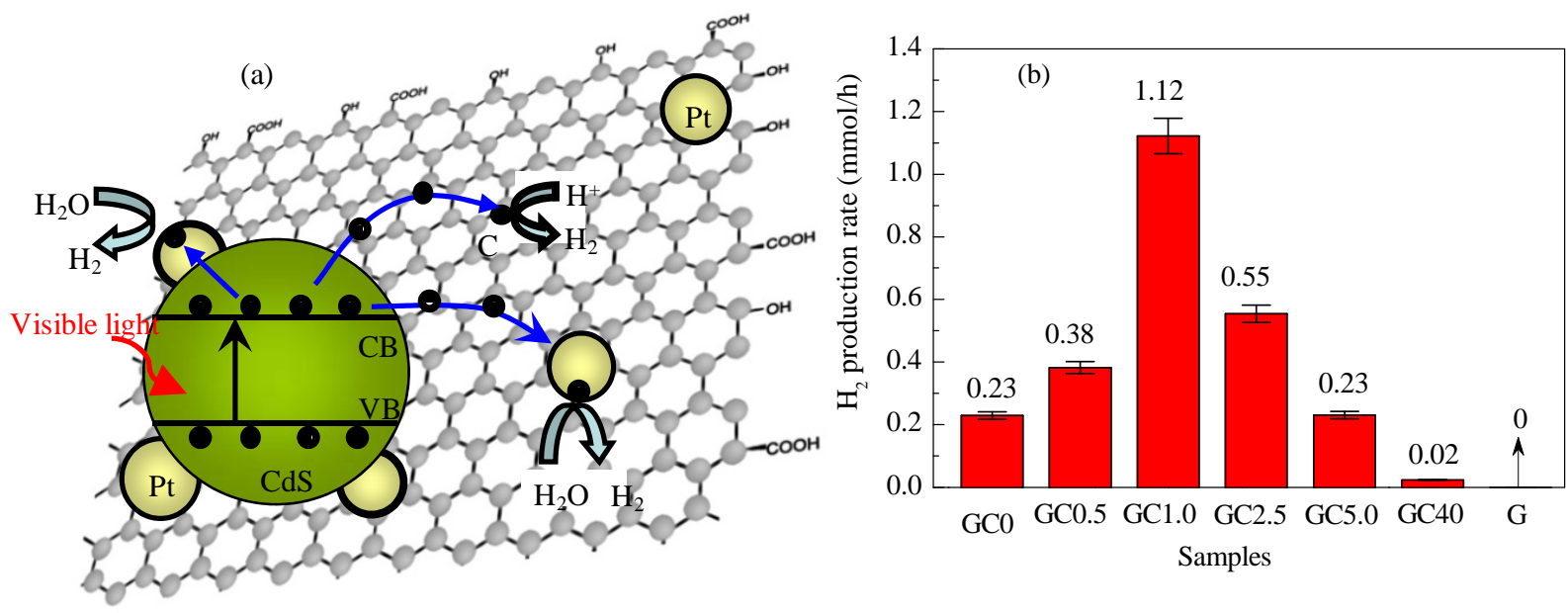

Fig. 6. Schematic illustration of charge separation and transfer in the graphene-CdS system under visible light (a) and comparison of $\mathrm{H}_{2}$ production rate of graphene-CdS samples (b). The weight ratios of $\mathrm{GO}$ to $\mathrm{Cd}(\mathrm{Ac})_{2} \cdot 2 \mathrm{H}_{2} \mathrm{O}$ were $0,0.5 \%, 1.0 \%, 2.5 \%, 5.0 \%$, and $40 \%$, and the samples were labeled as GC0, GC0.5, GC1.0, GC2.5, GC5.0, and GC40, respectively. Reproduced with permission from Ref. [61]; copyright 2011, American Chemical Society. 

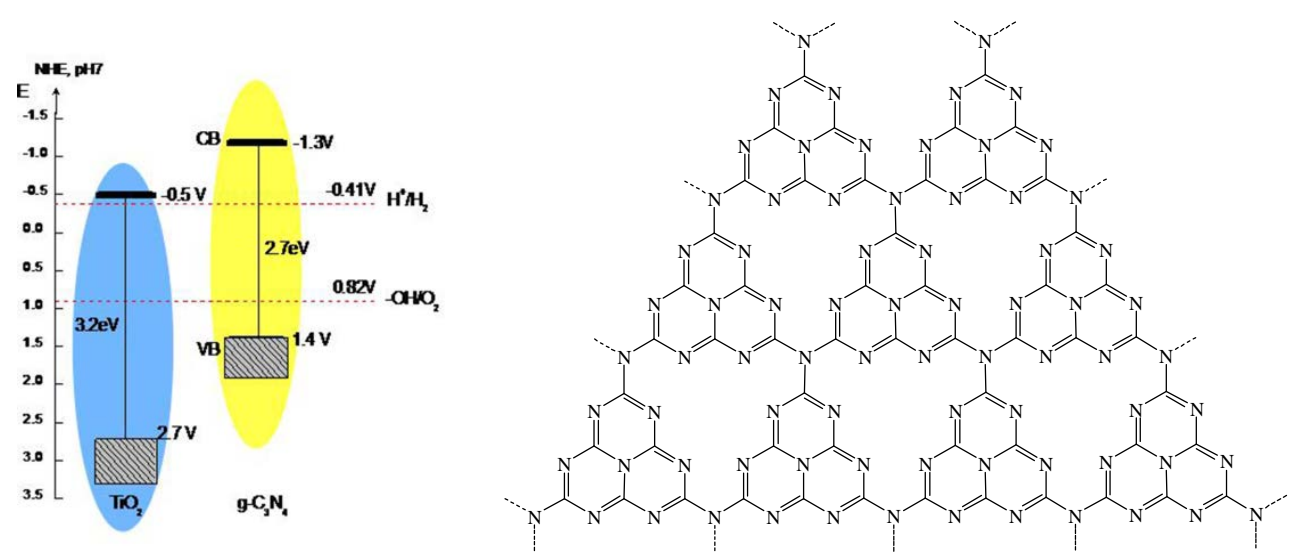

Fig. 7. Band gap structure of g- $\mathrm{C}_{3} \mathrm{~N}_{4}$ compared with titanium dioxide $\left(\mathrm{TiO}_{2}\right)$, and the idealized chemical structure of graphitic carbon nitrides.

$\mathrm{C}_{60}$ [73], polyethylene [74], graphite-like carbon [75], and graphene [76]) hybridized semiconductors were also developed as efficient photocatalysts for environmental purification. Very recently, a plasmon-based photocatalyst was applied to the degradation of pollutants under visible light irradiation. Huang and co-researchers showed that plasmon-based photocatalysts (for example, Ag@AgCl and Ag@AgBr) with strong absorption in the visible light region exhibited high efficiency in the degradation of organic dyes [77,78].

\subsubsection{Materials for photocatalytic water splitting}

Hydrogen is considered as an ideal next generation energy carrier. Achievements in photocatalytic water splitting will help overcome the global energy crisis and environmental pollution by converting solar energy and $\mathrm{CO}_{2}$ into high energy chemical fuels. To this end, the design of effective photocatalysts is necessary to give high efficiency in hydrogen generation on a large scale. Water splitting not only relies strongly on light harvesters but also on surface junctions and cocatalysts to promote charge separation and to lower the reaction overpotential.

Chen et al. [79] showed that disorder-engineered black $\mathrm{TiO}_{2}$ exhibited superior solar-driven photocatalytic activity in hydrogen evolution with electron donors, although the challenge still exist for overall water splitting by the black $\mathrm{TiO}_{2}$.

Heterophase junction and heterojunction photocatalysts are

(a)

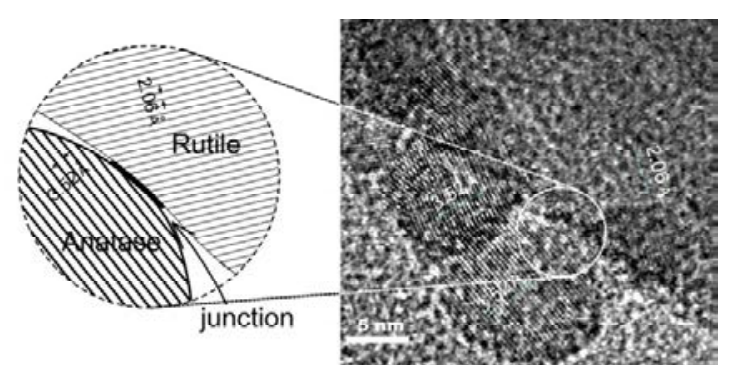

potential candidates for photocatalytic water splitting. Anatase/rutile $\mathrm{TiO}_{2}$ [80] and $\mathrm{MoS}_{2} / \mathrm{CdS}$ [81] heterojunction photocatalysts showed enhanced efficiency in photocatalytic hydrogen evolution because of the improved separation of electron-hole pairs (see Fig. 8). Li and coworkers [82] found a $\mathrm{Pt}-\mathrm{PdS} / \mathrm{CdS}$ catalyst with a quantum efficiency of $93 \%$ at 420 $n$ m with a sacrificial reagent $\mathrm{Na}_{2} \mathrm{~S}$, where $\mathrm{Pt}$ and $\mathrm{PdS}$ function as reductive and oxidative cofactors, respectively. Both oxidative and reductive promotion of catalytic rates significantly accelerated charge separation and transformation at the material interfaces. It is probably the highest quantum efficiency (93\%) of hydrogen evolution worldwide for the half water splitting reaction using artificial materials in the presence of sacrificial organics. This is comparable to natural biological systems that are very efficient in the transfer of electron and energy in tandem manner.

Loading the proper noble metal cocatalyst (Pt, Pd, $\mathrm{Ru}$ and $\mathrm{Ag}$ etc.) on the surface of the catalyst is a vital strategy to enhance photocatalytic hydrogen evolution in the presence of sacrificial reagents. Very recently, however, alternative cocatalysts based on cheap and abundant non-noble metals have been found. With the use of $\mathrm{MoS}_{2}$ /graphene [83] or Cu/graphene [84] as an efficient cocatalyst, the quantum efficiency of photocatalytic hydrogen evolution was dramatically promoted. The cocatalyst design for catalyzing overall water splitting is highly desirable.

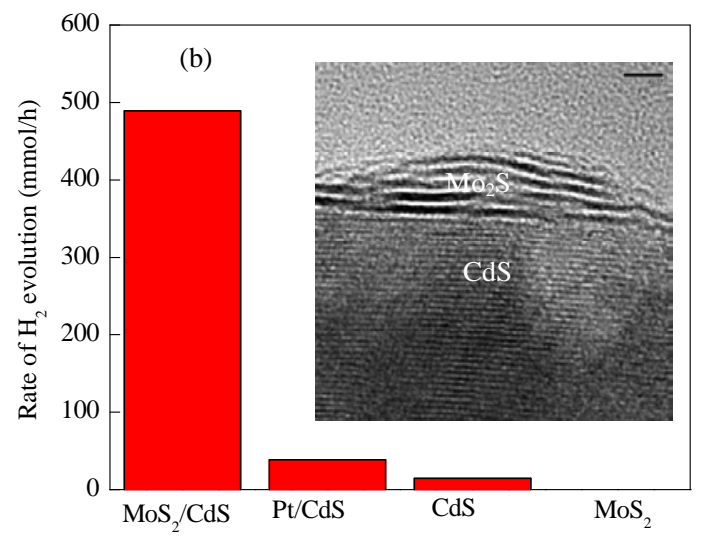

Fig. 8. HRTEM image of a $\mathrm{TiO}_{2}$ (anatase)/ $\mathrm{TiO}_{2}$ (rutile) sample (a) [80] and the rate of $\mathrm{H}_{2}$ evolution on $\mathrm{MoS}_{2}, \mathrm{CdS}, \mathrm{MoS} / \mathrm{CdS}$, and mechanical mixture of $\mathrm{MoS}_{2}$ and CdS under visible light $(\lambda>420 \mathrm{~nm})$, and the magnified HRTEM image of $1 \mathrm{wt} \% \mathrm{MoS}_{2} / \mathrm{CdS}$ (b). Reproduced with permission from Refs. [80,81], copyright 2008, Wiley-VCH and American Chemical Society, respectively. 
This relies not only on the nanostructural design of co-catalysts but also on the textural engineering of semiconductors for the control of directional charge transfer and to spatially separate the water redox reactions on the two surface side membranes or in the exterior/interior of hollow nanospheres, as well as to prevent the reverse reaction of $\mathrm{H}_{2}$ and $\mathrm{O}_{2}$ by core/shell design of reductive co-factors.

\subsubsection{Materials for photocatalytic conversion of $\mathrm{CO}_{2}$}

The photocatalytic conversion of $\mathrm{CO}_{2}$ has drawn the attention of Chinese researchers and scientists [85] because $\mathrm{CO}_{2}$ is an abundant $\mathrm{C} 1$ feedstock for the production of high value chemicals. The reduction of $\mathrm{CO}_{2}$ can be conducted on composite catalysts and metal loaded composite catalysts, including $\mathrm{Cu}-\mathrm{TiO}_{2}, \quad \mathrm{MoO}_{3}-\mathrm{TiO}_{2}, \quad \mathrm{WO}_{3}-\mathrm{TiO}_{2}, \quad \mathrm{~V}_{2} \mathrm{O}_{5}-\mathrm{TiO}_{2}, \quad \mathrm{SnO}_{2}-\mathrm{TiO}_{2}$, $\mathrm{M} / \mathrm{MoO}_{3}-\mathrm{TiO}_{2}, \mathrm{M} / \mathrm{WO}_{3}-\mathrm{TiO}_{2}, \mathrm{M} / \mathrm{V}_{2} \mathrm{O}_{5}-\mathrm{TiO}_{2}$, and $\mathrm{M} / \mathrm{SnO}_{2}-\mathrm{TiO}_{2}(\mathrm{M}$ $=\mathrm{Pd}, \mathrm{Cu}, \mathrm{Ag}$ ] [86-89]. In addition to $\mathrm{TiO}_{2}$-based materials, other materials also play an important role in the photocatalytic reduction of $\mathrm{CO}_{2}$, such as tantalates, germanates, zirconates, vanadates and niobates. For example, Zou's group [90] found that ultra-long and ultra-thin $\mathrm{Zn}_{2} \mathrm{GeO}_{4}$ nanoribbons promoted the production of hydrocarbon fuel $\left(\mathrm{CH}_{4}\right)$ in the presence of water vapor and $\mathrm{CO}_{2}$. The high photocatalytic activity of the $\mathrm{Zn}_{2} \mathrm{GeO}_{4}$ nanoribbons was attributed to its high specific surface area, superior crystal quality and efficient charge separation [90] (see Fig. 9). Similarly, sheaf-like $\mathrm{Zn}_{2} \mathrm{GeO}_{4}$ [91], $\mathrm{Zn}_{2} \mathrm{GeO}_{4}$ nanorods [92], $\mathrm{ZnGa}_{2} \mathrm{O}_{4}$ [93], and $\mathrm{ZnAl}_{2} \mathrm{O}_{4}$-modified mesoporous ZnGaON [94] were also applied to the photoreduction of $\mathrm{CO}_{2}$. Recently, it was also demonstrated that the photocatalytic reduction of $\mathrm{CO}_{2}$ to $\mathrm{HCOO}^{-}$was possible over an amine-functionalized Ti-containing MOF, namely $\mathrm{NH}_{2}$-MIL-125(Ti) [59]. In comparison with the parent MIL-125(Ti), NH2-MIL-125(Ti) exhibited increased light absorption ability, better $\mathrm{CO}_{2}$ uptake capacity, and enhanced photocatalytic reduction properties [59]. The work also high- lighted the chemical diversity available in selecting metal ions and organic linkers to construct photocatalytic microporous structures that have the combined benefits of a porous framework, metal redox chemistry, organocatalysis, and chromophoric antenna for artificial photosynthesis in defined and 'homogeneous' chemical environments. This is a valuable model photocatalyst for studying 'single-site' photocatalysis.

\subsubsection{Materials for photocatalytic organic synthesis}

Photocatalysis provides a green chemical route for organic functional group transformation under mild conditions. So far, researchers have looked at photocatalytic selective oxidation of alcohol and amines, oxidation of cyclohexane, methoxycarbonylation of the olefin, epoxidation of styrene into styrene oxide, photoreduction of nitroaromatic compounds, and $\mathrm{C}-\mathrm{C}$ coupling reactions.

For the photocatalytic selective oxidation of alcohol, a system containing Alizarin Red (AR) dye-sensitized $\mathrm{TiO}_{2}$ and nitroxyl radicals was developed by Zhao's group [95]. The system showed activity under visible light irradiation [95], and avoided the generation of reactive and un-selective hydroxyl radicals on $\mathrm{TiO}_{2}$. In addition, the pretreatment of $\mathrm{TiO}_{2}$ and $\mathrm{Si} / \mathrm{Ti}$ with Brönsted acids was reported by the same group to enhance the reaction rate without the sacrifice of selectivity during the oxidation of alcohols [96]. In addition, the selective photocatalytic oxidation of benzyl alcohol into benzaldehyde was performed over single crystal rutile $\mathrm{TiO}_{2}$ nanorods under visible light irradiation. Graphene (GR)-based nanocomposites and graphene oxide (GO)-based composites (GR-TiO 2 [97], CdS-GR-TiO 2 [98]) have also been used in the photocatalytic selective oxidation of alcohols.

For the aerobic photocatalytic oxidation of amines, various benzylic imines were selectively generated from amines over $\mathrm{TiO}_{2}$ in air $[99,100]$. For application in methoxycarbonylation of the olefin, methyl carboxylates can be produced from a solution
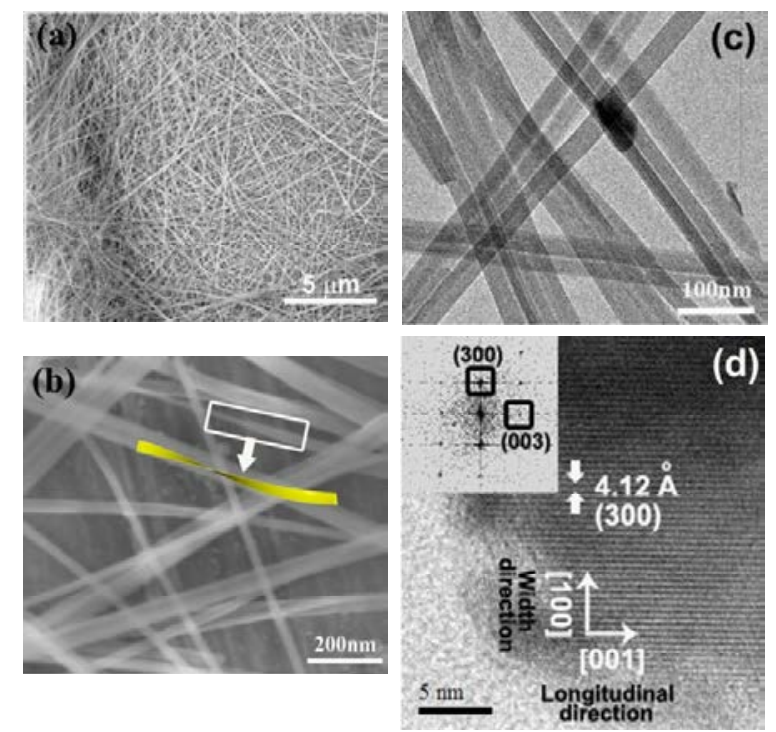
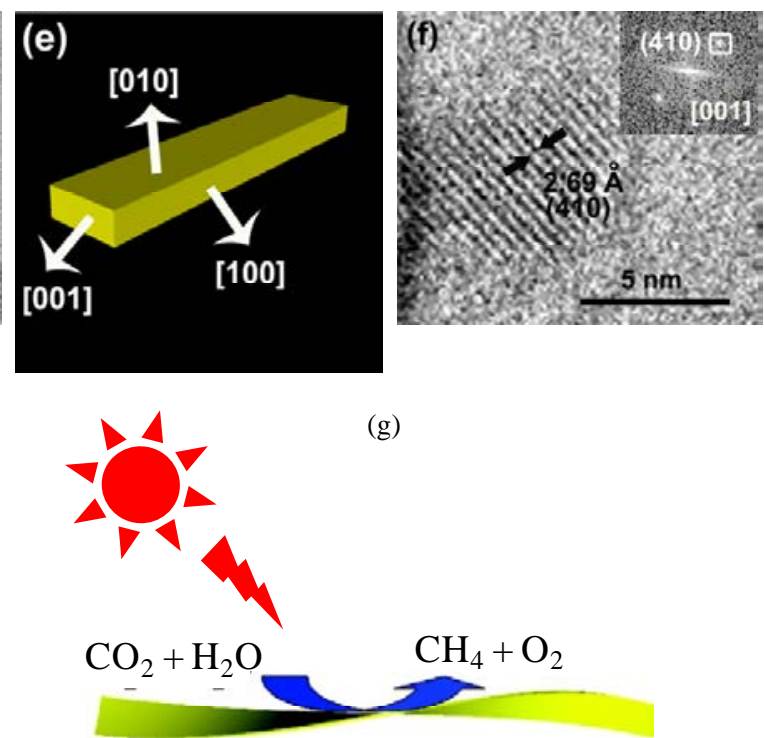

Fig. 9. FE-SEM (a, b), TEM (c), and HRTEM (d) images of $\mathrm{Zn}_{2} \mathrm{GeO}_{4}$ nanoribbons. The inset of (d) shows the FFT pattern obtained from the HRTEM image; structural model of a nanoribbon (e); HRTEM image taken along [001] (f); schematic of photocatalytic reduction of $\mathrm{CO}_{2}$ on the surface of $\mathrm{Zn}_{2} \mathrm{GeO}_{4}$ nanoribbons (g). Reproduced with permission from Ref. [90]; copyright 2010, American Chemical Society. 
containing bis(pentane-2,5-dionato) cobalt (II), olefin and methanol-acetone [101]. In the field of photocatalytic epoxidation of styrene into styrene oxide, high selectivity was achieved over $\mathrm{TiO}_{2} / \mathrm{SiO}_{2}$ nanoparticles by photoactivated molecular oxygen under mild conditions [102]. As to the photoreduction of nitroaromatic compounds, the modification of $\mathrm{TiO}_{2}$ with asparagine, serine and phenylalanine was reported to show enhanced photocatalytic reduction ability as compared with bare $\mathrm{TiO}_{2}$ [103]. Zhu's group showed photocatalytic C-C coupling from ethanol while producing $\mathrm{H}_{2}$ by $\mathrm{Pt} / \mathrm{TiO}_{2}$ in a water-alcohol medium under UV light irradiation [104]. The formation of - $\mathrm{CH}_{3} \mathrm{CHOH}$ radicals was demonstrated to induce the $\mathrm{C}-\mathrm{C}$ coupling reaction, and this scheme can be extended to various alcohols for the chemical production of fine chemicals such as diols under very mild photochemical conditions as compared to the traditional harsh reaction conditions [104].

\subsection{Mechanism of photocatalysis}

An understanding of the reaction mechanism and kinetics is helpful for the design of efficient photocatalysts and reactors. Zhao's group have studied the mechanism of the photocatalytic degradation of dye pollutants under visible light irradiation since 1995 [105]. The visible light-irradiation mechanism is quite different from the UV-irradiation pathway described previously $[106,107]$. Moreover, the mechanism of the photocatalytic activation of molecular oxygen was illustrated during selective organic oxidation by the same group. In the photocatalytic oxidation of alcohols over $\mathrm{TiO}_{2}$ in a benzotrifluoride solvent, an unanticipated oxygen atom transfer from molecular oxygen to alcohol was found (Fig. 10) [108]. The formation of the Ti intermediate (Fig.11, 4) with a side-on peroxide [108] was examined by using O-labeling experiments. In addition, they also found that the conversion in the photocatalytic oxidation of alcohols over $\mathrm{TiO}_{2}$ can be greatly improved by surface acidification to generate more Brönsted acid sites and the incorporation of a small quantity of $\mathrm{SiO}_{2}$ [96]. This again highlighted the importance of surface acidity in promoting photocatalysis. The reason is that the protons of Brönsted acids accelerated the decomposition of the relatively stable side-on peroxide, thus effectively activating the $\mathrm{Ti}-\mathrm{OH}_{2}$ catalytic sites [96]. The surface acidic sites can also have the value of promoting charge separation and increasing the surface that is reactive towards the substrates.

The relationship between the photoluminescence features of $\mathrm{TiO}_{2}$ and the photo-assisted reaction of the water/methanol

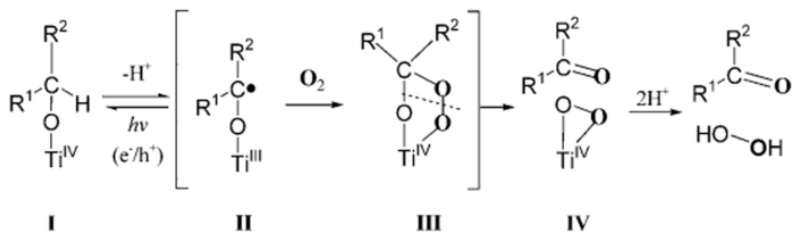

Fig. 10. Oxygen transfer process in $\mathrm{TiO}_{2}$ photocatalytic oxidation of alcohols in BTF solvent in the presence $\mathrm{O}_{2}$. Reproduced with permission from Ref. [108]; copyright 2009, Wiley-VCH.

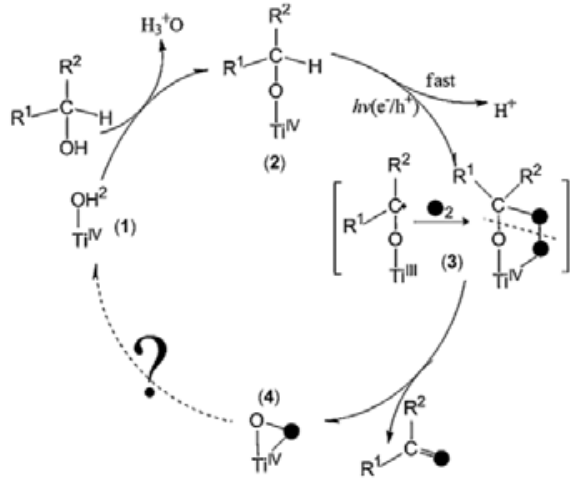

Fig. 11. Reaction cycle in $\mathrm{TiO}_{2}$ photocatalytic oxidation of alcohols. Reproduced with permission from Ref. [96]; copyright 2010, Wiley-VCH.

mixture was investigated. Activated electrons trapped in the oxygen vacancies of anatase were promptly transferred to Pt to participate in the photoinduced process, while electrons trapped in the intrinsic defects of rutile were delayed [109]. In situ FTIR and nanosecond to second time resolved IR measurements were used to investigate photocatalytic $\mathrm{H}_{2}$ production on $\mathrm{Pt} / \mathrm{TiO}_{2}$ catalyst in methanol [110]. Pan observed the photocatalytic reaction for the degradation of methylene blue with $\mathrm{P} 25 \mathrm{TiO}_{2}$ with a high resolution transmission electron microscope (HRTEM) [111]. Their results indicated that the vital intermediate step during photocatalysis is the lattice distortion on the anatase $\mathrm{TiO}_{2}\{101\}$ surface due to the chemical adsorption of methylene blue molecules [111]. A new photocatalysis mechanism was proposed that comprised an electron degradation mechanism instead of the hole degradation mechanism that dominates the photocatalytic processes, from the comparing of the photocatalytic bactericidal effect on different crystal faces of bulk ZnO crystal [112].

Theoretical calculations have been applied to the study of the photocatalytic mechanism. The photocatalysis of partially deuterated methanol $\left(\mathrm{CD}_{3} \mathrm{OH}\right)$ and $\mathrm{H}_{2} \mathrm{O}$ on $\mathrm{TiO}_{2}\{110\}$ at 400 $\mathrm{nm}$ was investigated by theoretical calculation [113]. The first principles slab calculation and the periodic continuum solvation model were used to look at the reaction network for the oxygen evolution reaction (OER) on various anatase surfaces [114]. Another work applied density functional theory (DFT) calculations and the periodic continuum solvation model to investigate the effect of particle size and shape of $\mathrm{TiO}_{2}$ anatase nanoparticles on the photocatalytic activity of the oxygen evolution reaction (OER) [115].

\section{Conclusion remarks}

Developments in photocatalysis in the past 40 years in China include the design of light converting materials and co-factors, applications of photocatalytic technology, and mechanism and kinetic studies. Some vital problems still have to be solved, such as the construction of efficient and stable visible light-responsive photocatalysts, design of an overall water splitting system, and nanodevice fabrication. The synthesis of nanoscale materials and their applications in pollutant 
decomposition have broadened the scope of photocatalysis. There is still a long way to go to achieve highly effective overall water splitting and $\mathrm{CO}_{2}$ reduction by an efficient and stable photocatalytic system. Growing activity in this mature but still emerging area in the future will help to address global energy and environment problems in a sustainable manner.

Here we only briefly described some domestic research progress in photocatalysis in China, but many excellent works cannot be included as the total publications already exceed 11,000 . More comprehensive and topical reviews that focus on different aspects are certainly needed in the future. It is clear that considerable and significant work has been performed on photocatalysis by Chinese researchers, and it is a very active research field in China.

After 40 years of intensive studies on artificial photosynthesis, it seems on the edge of innovative breakthroughs that calls for broad and deep international/domestic collaboration from various research areas including chemistry, physics, catalysis, biology, materials science, surface science and so on. Indeed, many governments have launched big joint research centers/teams (The Joint Center for Artificial Photosynthesis in CalTech and Berkeley, Light2Hydrogen Project in Germany, The Action Plan for Solar Energy in China, and The Joint Artificial Photosynthesis Project in Japan) as efforts to achieve breakthrough innovations in energy production with artificial photosynthesis.

\section{References}

[1] Fujishima A, Honda K. Nature, 1972, 238: 37

[2] Tong H, Ouyang S X, Bi Y P, Umezawa N, Oshikiri M, Ye J H. Adv Mater, 2012, 24: 229

[3] Jin Z S. Acta Energiae Solaris Sinica, 1982, 3: 179

[4] Gao F, Li S B, Chen Y W. Acta Energiae Solaris Sinica, 1981, 4: 396

[5] Gao F, Li S B, He Y G. Acta Energiae Solaris Sinica, 1983, 1: 58

[6] Kiwi J, Grätzel M. Angew Chem, Int Ed, 1979, 18: 624

[7] Chen L H, Gu W Z, Zhu X W, Wang F D, Song Y Z, Hu J H. J Photochem Photobio A, 1993, 74: 85

[8] Li S B. J Mol Catal, 1988, 2: 217

[9] Wang Z H, Zhuang Q X. J Photochem Photobio A, 1993, 75: 105

[10] Wang S S, Wang Z H, Zhuang Q X. Appl Catal B, 1992, 1: 257

[11] Chen X B, Mao S S. Chem Rev, 2007, 107: 2891

[12] Chen X B. Chin J Catal (陈晓波. 催化学报), 2009, 30: 839

[13] Jing L Q, Qu Y C, Wang B Q, Li S D, Jiang B J, Yang L B, Fu W, Fu H G, Sun J Z. Sol Energy Mater Sol Cells, 2006, 90: 1773

[14] Linsebigler A L, Lu G Q, Yates J T. Chem Rev, 1995, 95: 735

[15] Gao Z Q, Yang S G, Ta N, Sun C. J Hazard Mater, 2007, 145: 424

[16] Wang Y W, Zhang L Z, Deng K J, Chen X Y, Zou Z G.J Phys Chem C, 2007, 111: 2709

[17] Wu X F, Song H Y, Yoon J M, Yu Y T, Chen Y F. Langmuir, 2009, 25: 6438

[18] Zhang N, Liu S Q, Fu X Z, Xu Y J.J Phys Chem C, 2011, 115: 9136

[19] Yang H G, Sun C H, Qiao S Z, Zou J, Liu G, Smith S C, Cheng H M, Lu G Q. Nature, 2008, 453: 638

[20] Liu S W, Yu J G, Jaroniec M. J Am Chem Soc, 2010, 132: 11914

[21] Pan J, Liu G, Lu G Q, Cheng H M. Angew Chem, Int Ed, 2011, 50: 2133

[22] Han X G, Kuang Q, Jin M S, Xie Z X, Zheng L S. J Am Chem Soc, 2009, 131: 3152
[23] Guo W X, Zhang F, Lin C J, Wang Z L. Adv Mater, 2012, 24: 4761

[24] Yu J C, Zhang L Z, Yu J G. Chem Mater, 2002, 14: 4647

[25] Wang X C, Yu J C, Ho C M, Hou Y D, Fu X Z. Langmuir, 2005, 21 : 2552

[26] Yu J G, Su Y R, Cheng B. Adv Funct Mater, 2007, 17: 1984

[27] Yu J G, Zhang L J, Cheng B, Su Y R. J Phys Chem C, 2007, 111: 10582

[28] Yu J G, Wang G H.J Phys Chem Solids, 2008, 69: 1147

[29] Yu H G, Yu J G, Cheng B, Lin J. J Hazard Mater, 2007, 147: 581

[30] Zhang F X, Zhang X, Chen J X, Liu Zh G, Gao W L, Jin R C, Guan N J. Chin J Catal (章福祥, 张秀, 陈继新, 刘智广, 高文亮, 金瑞彩, 关 乃佳. 催化学报), 2003, 24: 877

[31] Wang P, Huang B B, Dai Y, Whangbo M H. Phys Chem Chem Phys, 2012, 14: 9813

[32] Yu J G, Dai G P, Huang B B. J Phys Chem C, 2009, 113: 16394

[33] Tong T Z, Zhang J L, Tian B Z, Chen F, He D N. J Hazard Mater, 2008, 155: 572

[34] Yu J C, Yu J G, Ho W K, Jiang Z T, Zhang L Z. Chem Mater, 2002, 14: 3808

[35] Yang P, Lu C, Hua N P, Du Y K. Mater Lett, 2002, 57: 794

[36] Li X Z, Li F B, Yang C L, Ge W K. J Photochem Photobiol A, 2001, 141: 209

[37] Yu H B, Chen S, Quan X, Zhao H M, Zhang Y B. Environ Sci Technol, 2008, 42: 3791

[38] Huang H J, Li D Z, Lin Q, Zhang W J, Shao Y, Chen Y B, Sun M, Fu X Z. Environ Sci Technol, 2009, 43: 4164

[39] Zhang L W, Wang Y J, Xu T G, Zhu S B, Zhu Y F. J Mol Catal A, 2010, 331: 7

[40] Zhang Y H, Tang Z R, Fu X Z, Xu Y J. ACS Nano, 2010, 4: 7303

[41] Jin Z L, Zhang X J, Lu G X, Li S B. J Mol Catal A, 2006, 259: 275

[42] Jin Z L, Zhang X J, Li Y X, Li S B, Lu G X. Catal Commun, 2007, 8: 1267

[43] Fu X Zh, Ding Zh X, Su W Y, Li D Zh. Chin J Catal (付贤智, 丁正新, 苏文悦, 李旦振. 催化学报), 1999, 20: 321

[44] Su W Y, Chen Y L, Fu X Zh, Wei K M. Chin J Catal (苏文悦, 陈亦琳, 付贤智, 魏可镁. 催化学报), 2001, 22: 175

[45] Yu J C, Zhang L Z, Zheng Z, Zhao J C. Chem Mater, 2003,15: 2280

[46] Hou Y D, Wu L, Wang X C, Ding Z X, Li Z H, Fu X Z. J Catal, 2007, 250: 12

[47] Jiang J, Zhao K, Xiao X Y, Zhang L Z. J Am Chem Soc, 2012, 134: 4473

[48] Huang J H, Ding K N, Hou Y D, Wang X C, Fu X Z. ChemSusChem, 2008, 1: 1011

[49] Liang S J, Wu L, Bi J H, Wang W J, Gao J, Li Z H, Fu X Z. Chem Commun, 2010, 46: 1446

[50] Ma L L, Sun H Z, Zhang Y G, Lin Y L, Li J L, Wang E K, Yu Y, Tan M, Wang J B. Nanotechnology, 2008, 19: 115709

[51] Xie Z, Zhu Y G, Xu J, Huang H T, Chen D, Shen G Z. CrystEngComm, 2011, 13: 6393

[52] Cao S W, Zhu Y J.J Phys Chem C, 2008, 112: 6253

[53] Wu L, Bi J H, Li Z H, Wang X X, Fu X Z. Catal Today, 2008, 131: 15

[54] Tang J W, Zou Z G, Ye J H. Angew Chem, Int Ed, 2004, 43: 4463

[55] Guo Y H, Li D F, Hu C W, Wang Y H, Wang E B. Chem J Chin U, 2001, 22: 1453

[56] Yan G Y, Wang X X, Fu X Z, Li D Z. Catal Today, 2004, 93-95: 851

[57] Li L, Li G D, Yan C, Mu X Y, Pan X L, Zou X X, Wang K X, Chen J S. Angew Chem, Int Ed, 2011, 50: 8299

[58] Fu Y H, Sun D R, Chen Y J, Huang R K, Ding Z X, Fu X Z, Li Z H. Angew Chem, Int Ed, 2012, 124: 3420

[59] Liu G, Niu P, Yin L C, Cheng H M. J Am Chem Soc, 2012, 134: 9070

[60] Xia X H, Jia Z J, Yu Y, Liang Y, Wang Z, Ma L L. Carbon, 2007, 45: 717 


\section{Graphical Abstract}

Chin. J. Catal., 2013, 34: 524-535 doi: 10.1016/S1872-2067(12)60548-8

\section{Advances in photocatalysis in China \\ ZHENG Yun, PAN Zhiming, WANG Xinchen* \\ Fuzhou University}

This review briefly presented developments in photocatalysis in China and focused on materials, modifications, and reaction mechanisms. The photocatalytic process is an artificial photosynthesis process for water splitting and $\mathrm{CO}_{2}$ reduction by semiconductors using sunlight.

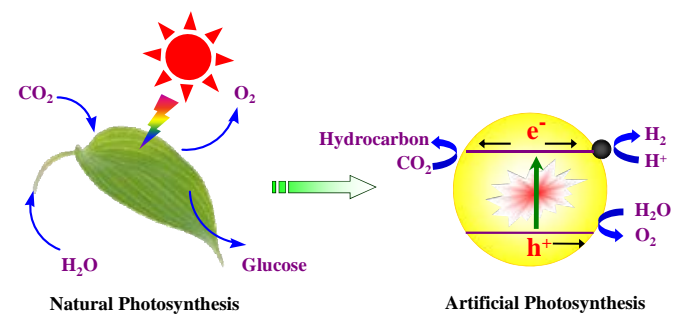

[61] Li Q, Guo B D, Yu J G, Ran J R, Zhang B H, Yan H J, Gong J R. J Am Chem Soc, 2011, 133: 10878

[62] An X Q, Yu J C, Wang Y, Hu Y M, Xu X L, Zhang G J. J Mater Chem, 2012, 22: 8525

[63] Wang X C, Maeda K, Thomas A, Takanabe K, Xin G, Carlsson J M, Domen K, Antonietti M. Nat Mater, 2009, 8: 76

[64] Zhang J S, Zhang G G, Chen X F, Lin S, Möhlmann L, Dolega G, Lipner G, Antonietti M, Blechert S, Wang X C. Angew Chem, Int Ed, 2012, 51: 3183

[65] Cui Y J, Ding Z X, Liu P, Antonietti M, Fu X Z, Wang X C. Phys Chem Chem Phys, 2012, 14: 1455

[66] Zhao W, Ma W H, Chen C C, Zhao J C, Shuai Z G. J Am Chem Soc, 2004, 126: 4782

[67] Wu J C S, Chen C H. J Photochem Photobio A, 2004, 163: 509

[68] Hsien Y H, Chang C F, Chen Y H, Cheng S. Appl Catal B, 2001, 31: 241

[69] Wang K H, Hsieh Y H, Chou M Y, Chang C Y. Appl Catal B, 1999, 21: 1

[70] Wei T Y, Wan C C. Ind Eng Chem Res, 1991, 30: 1293

[71] Tsai S J, Cheng S. Catal Today, 1997, 33: 227

[72] Zhang C, Zhu Y F. Chem Mater, 2005, 17: 3537

[73] Zhu S B, Xu T G, Fu H B, Zhao J C, Zhu Y F. Environ Sci Technol, 2007, 41: 6234

[74] Zhang H, Zong R L, Zhao J C, Zhu Y F. Environ Sci Technol, 2008, 42: 3803

[75] Zhang L W, Fu H B, Zhu Y F. Adv Funct Mater, 2008, 18: 2180

[76] Xu T G, Zhang L W, Cheng H Y, Zhu Y F. Appl Catal B, 2011, 101: 382

[77] Wang P, Huang B B, Qin X Y, Zhang X Y, Dai Y, Wei J Y, Whangbo M H. Angew Chem, Int Ed, 2008, 47: 7931

[78] Wang P, Huang B B, Zhang X Y, Qin X Y, Jin H, Dai Y, Wang Z Y, Wei J Y, Zhan J, Wang S Y, Wang J P, Whangbo M H. Chem Eur J, 2009, 15: 1821

[79] Chen X B, Liu L, Yu P Y, Mao S S. Science, 2011, 331: 746

[80] Zhang J, Xu Q, Feng Z C, Li M J, Li C. Angew Chem, Int Ed, 2008, 47: 1766

[81] Zong X, Yan H J, Wu G P, Ma G J, Wen F Y, Wang L, Li C. J Am Chem Soc, 2008, 130: 7176

[82] Yan H J, Yang J H, Ma G J, Wu G P, Zong X, Lei Z B, Shi J Y, Li C. J Catal, 2009, 266: 165

[83] Xiang Q J, Yu J G, Jaroniec M. J Am Chem Soc, 2012, 134: 6575

[84] Lv X J, Zhou S X, Zhang C, Chang H X, Chen Y, Fu W F. J Mater Chem, 2012, 22: 18542

[85] Wu C P, Zhou Y, Zou Zh G. Chin J Catal (吴聪萍, 周勇, 邹志刚. 催 化学报), 2011, 32: 1565

[86] Tseng I H, Chang W C, Wu J C S. Appl Catal B, 2002, 37: 37

[87] Tseng I H, Chang W C, Chou H Y. J Catal, 2004, 221: 432

[88] Chen S Zh, Zhong Sh H, Xiao X F. Chin J Catal (陈嵡哲, 钟顺和, 肖
秀芬. 催化学报), 2003, 24: 67

[89] Mei Ch S, Zhong Sh H. Chin J Catal (梅长松, 钟顺和. 催化学报), 2004, 25: 937

[90] Liu Q, Zhou Y, Kou J H, Chen X Y, Tian Z P, Gao J, Yan S C, Zou Z G. J Am Chem Soc, 2010, 132: 14385

[91] Liu Q Zhou Y, Tian Z P, Chen X Y, Gao J, Zou Z G. J Mater Chem, 2012, 22: 2033

[92] Yan S C, Wan L J, Li Z S, Zou Z G. Chem Commun, 2011, 47: 5632

[93] Yan S C, Ouyang S X, Gao J, Yang M, Feng J Y, Fan X X, Wan L J, Li Z S, Ye J H, Zhou Y, Zou Z G. Angew Chem, Int Ed, 2010, 49: 6400

[94] Yan S C, Yu H, Wang N Y, Li Z S, Zou Z G. Chem Commun, 2012, 48: 1048

[95] Zhang M, Chen C C, Ma W H, Zhao J C. Angew Chem, Int Ed, 2008, 47: 9730

[96] Wang Q, Zhang M, Chen C C, Ma W H, Zhao J C. Angew Chem, Int $E d, 2010,49: 7976$

[97] Zhang Y H, Tang Z R, Fu X Z, Xu Y J. ACS Nano, 2011, 5: 7426

[98] Zhang N, Zhang Y H, Pan X Y, Yang M Q, Xu Y J. J Phys Chem C, 2012, 116: 18023

[99] Lang X J, Ji H W, Chen C C, Ma W H, Zhao J C. Angew Chem, Int Ed, 2011, 50: 3934

[100] Lang X J, Ma W H, Zhao Y B, Chen C C, Ji H W, Zhao J C. Chem Eur J, 2012, 18: 2624

[101] Tao Y T, Yeh W L, Tu C L,Chow Y L.J Mol Catal, 1991, 67: 105

[102] Li XY, Kutal C. J Mater Sci Lett, 2002, 21: 1525

[103] Huang H Y, Zhou J H, Liu H L, Zhou Y H, Feng Y Y. J Hazard Mater, 2010, 178: 994

[104] Lu H Q, Zho J H, Li L, Gong L M, Zheng J F, Zhang L X,Wang Z J, Zhang J, Zhu Z P. Energy Environ Sci, 2011, 4: 3384

[105] Chen C C, Ma W H, Zhao J C. Chem Soc Rev, 2010, 39: 4206

[106] Wu T X, Liu G M, Zhao J C, Hidaka H, Serpone N. J Phys Chem B, 1998, 102: 5845

[107] Wu T X, Lin T, Zhao J C, Hidaka H, Serpone N. Environ Sci Technol, 1999, 33: 1379

[108] Zhang M, Wang Q Chen C C, Zang L, Ma W H, Zhao J C. Angew Chem Int Ed, 2009, 48: 6081

[109] Shi J Y, Chen J, Feng Z C, Chen T, Lian Y X, Wang X L, Li C. J Phys Chem C, 2007, 111: 693

[110] Chen T, Feng Z C, Wu G P, Shi J Y, Ma G J, Ying P L, Li C. J Phys Chem C, 2007, 111: 8005

[111] Zhang J, Zhang Y P, Lei Y K, Pan C X. Catal Sci Technol, 2011, 1: 273

[112] Wang Y H, Huang F, Pan D M, Li B, Chen D G, Lin W W, Chen X Y, Li R F, Lin Z. Chem Commun, 2009, 44: 6783

[113] Guo Q, Xu C B, Ren Z F, Yang W S, Ma Z B, Dai D X, Fan H J, Minton T K, Yang X M. J Am Chem Soc, 2012, 134: 13366

[114] Li Y F, Liu Z P, Liu L L, Gao W G. J Am Chem Soc, 2010, 132: 13008

[115] Li Y F, Liu Z P. J Am Chem Soc, 2011, 133: 15743 


\title{
国内光催化研究进展简述
}

\author{
郑云, 潘志明, 王心晨* \\ 福州大学光催化研究所, 化学化工学院, 福建福州350002
}

\begin{abstract}
摘要: 分1975 1985, 1985 1995和1995 2012三个时期简要介绍了国内光催化研究进展, 主要侧重于光催化材料及其改性、应用 和反应机理方面的研究进展, 并指出了当前光催化领域存在的一些重要问题和未来的发展趋势, 涉及到光解水、 $\mathrm{CO}_{2}$ 还原、环境 净化和选择性有机合成等方面.
\end{abstract}

关键词: 光催化; 半导体; 太阳能; 分解水

收稿日期: 2012-12-19. 接受日期: 2013-01-30. 出版日期: 2013-03-20.

*通讯联系人. 电话/传真: (0591)83920097; 电子信箱: xcwang@fzu.edu.cn

基金来源: 国家重点基础研究发展计划(973计划, 2013CB632405); 国家自然科学基金(21033003, 21173043).

本文的英文电子版由Elsevier出版社在ScienceDirect上出版(http://www.sciencedirect.com/science/journal/18722067).

\section{第二届国际生物质催化炼制大会(CatBior 2013)第一轮通知}

时间：2013 年 9 月22 25日 地点：辽宁省大连市

承办单位: 中国科学院大连化学物理研究所

\section{一、会议介绍}

国际生物质催化炼制大会 (International Congress on Catalysis for Biorefineries) 是在生物质催化转化技术蓬勃发展形 势下产生的国际性学术会议, 每两年召开一次, 由各大洲轮流 主办. 首届会议于 2011 年在西班牙召开, 第二届国际生物质 催化炼制大会 $\left(2^{\text {nd }}\right.$ International Congress on Catalysis for Biorefineries, http://catbior2013.dicp.ac.cn) 将于 2013 年 9 月 22 25 日在大连召开, 由中科院大连化学物理研究所承办.

本次大会旨在为全球生物质催化转化专家提供高水平的 学术交流平台, 展示生物质清洁高效催化转化技术的最新进 展, 并为来自世界各国的生物质转化工业界人士提供一个与 学界交流的契机, 从而推动生物质能源产业可持续发展.

\section{二、会议主题及征稿范围}

本次大会主题是生物质催化转化过程的基础和应用问题 研究, 征稿范围包括以下几个议题:

1. 纤维素、半纤维素、木质素及全生物质催化转化;

2. 碳水化合物及糖衍生物催化转化;

3. 油脂、微藻、脂肪及相关副产品的催化炼制;

4. 生物质热转化及生物油精制;

5. 其它生物质催化转化过程.

\section{三、投稿要求及日期}

大会组委会热诚欢迎从事生物质转化研究与技术开发的 专家、同行及在读研究生积极投稿并莅临本届盛会, 亦欢迎对 生物质转化有兴趣的企业参会或赞助. 会议采用在线投稿方 式, 关于详细论文摘要的格式要求, 请登录会议网站查看: http://catbior2013.dicp.ac.cn/dct/page/65558.

征稿截止日期为 2013 年 4 月 1 日, 通过评审的会议论文
将在《催化学报》及《Catalysis Today》上分别以专刊的形式 发表.

更多会议详情, 参见网站: http://catbior2013.dicp.ac.cn

四、会议承办单位及联系人

大会组委会主席: 张涛

中国科学院大连化学物理研究所

地址：辽宁省大连市中山路 457 号

邮编: 116023

E-mail: taozhang@dicp.ac.cn

http://catbior2013.dicp.ac.cn

大会组委会副主席: 王爱琴

中国科学院大连化学物理研究所

地址：辽宁省大连市中山路 457 号

邮编: 116023

电话: 0411-84379348

传真: 0411-84375940

E-mail: aqwang@dicp.ac.cn

大会组委会秘书: 李昌志 李宁

中国科学院大连化学物理研究所

地址: 辽宁省大连市中山路 457 号

邮编: 116023

电话: 0411-84379738

传真: 0411-84375940

E-mail: catbior2013@dicp.ac.cn

(第二届国际生物质催化炼制大会组委会) 